\title{
Trade in night monkeys Aotus spp. in the Brazil-Colombia-Peru tri-border area: international wildlife trade regulations are ineffectively enforced
}

\author{
Angela M. Maldonado*, Vincent Nijman, Simon K. Bearder \\ Department of Anthropology and Geography, Oxford Brookes University, Gipsy Lane, Oxford OX3 0BP, UK
}

\begin{abstract}
This study describes significant levels of trade in 2 or possibly 3 species of night monkeys (Aotus nancymaae, A. vociferans and A. nigriceps) from the Brazil-Colombia-Peru tri-border area. All 3 countries are Party to the Convention on International Trade in Endangered Species of Wild Fauna and Flora (CITES) and there is no documented trade in night monkeys among these 3 countries in the CITES trade database. However, interviews with 43 traders/collectors in 11 communities in the 3 countries suggest that for the period 2007-2008, ca. 4000 night monkeys were traded, representing a monetary value of over USD 100000 for the traders and intermediaries. The interviewees indicated that the animals were sold to a biomedical laboratory in the tri-border area on the Colombian side of the border. The international nature of the trade and the large volume of night monkeys being traded indicate a violation of, and a failure to adhere to, international trade regulations. In order to conserve these important species, we suggest cooperative action from environmental and conservation authorities and the respective CITES Management Authorities in Colombia, Peru and Brazil to curb the trade, and urge the Colombian authorities to investigate the illegal importation of night monkeys by a biomedical laboratory in the border area.
\end{abstract}

KEY WORDS: CITES · Primate conservation · Amazonia $\cdot$ Biomedical research

\section{INTRODUCTION}

During the late 1960s and early 1970s, the Amazon basin was the main source for wild harvested neotropical primates for export to overseas markets (Mittermeier et al. 1994). Between 1961 and 1975, Peru legally exported 392396 primates (Neville 1975, 1977, Smith 1977) while Colombia exported 52848 primates between 1972 and 1975 (Smith 1978). During the early 1970s, Colombia and Peru, together with India, were the main source countries, supplying $65 \%$ of the total international market of primates for biomedical research (Held \& Wofle 1994). In India where 20000 juvenile monkeys were exported every year, wild populations of rhesus monkeys Macaca mulatta were drastically decimated by the demand for this species for the biomedical research and pharmaceutical markets (Southwick \& Siddiqi 2001). In all 3 coun- tries, the continuous exploitation of primates was carried out with minimal consideration of population status and distribution, data which are required to quantify extraction numbers (Bailey et al. 1974). The alarming official export figures which are quite possibly underestimates, caused an international debate, resulting in Peru and Colombia implementing national bans on the export of primates in 1973 and 1974 respectively (Held \& Wofle 1994).

In 1973, the Convention of International Trade in Endangered Species of Wild Fauna and Flora (CITES) came into force. This convention is an international agreement among governments which aims to ensure that international trade in wild animals and plants does not threaten their survival. Of the Amazonian countries, Brazil and Peru were the first to accede to CITES in 1975, and Colombia became a Party to it in 1981. 
In an attempt to compile baseline information on wild populations to allow for sustainable exploitation, biomedical organisations such as the Pan American Health Organization (PAHO) and the National Institutes of Health (NIH) of the United States funded census fieldwork in the neotropics. This provided primate density estimates in a few locations throughout the Peruvian, Colombian and Bolivian Amazon regions (Freese 1975, Heltne et al. 1975, Muckenhirn et al. 1975, Neville 1975, Castro 1978). These data were expected to be sufficient to convince governments that most of the species used in biomedical research (squirrel monkeys Saimiri spp., night monkeys Aotus spp., tamarins Saguinus spp., common marmosets Callithrix jacchus, and tufted capuchins Cebus apella) were common enough to allow extraction without compromising the stability of wild populations (Smith 1977, Mittermeier et al. 1994). Simultaneously, in order to reduce the capture of wild animals, the PAHO, the Peruvian government and San Marcos University set up the first in situ captive breeding centre for neotropical primates in 1975 in Iquitos, Peru. However, the higher costs involved in captive breeding due to longer quarantine and acclimatisation periods, training of personnel, and more stringent transport and import requirements, have contributed to the continuing demand for wild-caught monkeys (Mittermeier 1991, Held \& Wofle 1994).

In this study, we provide an overview of the trade in live-caught night monkeys Aotus spp. from the Brazil-Colombia-Peru tri-border area. The demand for these animals comes from the biomedical industry, and this is facilitated primarily through a biomedical research institute in the Amazonas Department, Colombia. Given the existing confusion on the taxonomic status of night monkeys in this part of Amazonia, we first provide an overview of the status of night monkeys, after which we present our data on trade volumes. We finish by providing clear recommendations on how to tackle the illegal trade of night monkeys in this region.

\section{Status of Aotus vociferans and A. nancymaae}

The genus Aotus is widely distributed throughout Central and South America (Hernandez-Camacho \& Cooper 1976, Hershkovitz 1983, Defler et al. 2001). Its taxonomic status has been a matter of academic dispute due to the wide number of different karyotypes reported without clear phenotypic distinctions between intra- and inter-population variations (Ruiz-Herrera et al. 2005, Defler \& Bueno 2007). The genus is divided into 2 groups: the red-necked species group distributed south of the Amazon-Solimões River and the grey-necked species group found mainly north of the Amazon River (Hershkovitz 1983, HernandezCamacho \& Defler 1989).

Our focus is mainly on the 2 species which are targeted for biomedical research, viz. the Amazonian night monkey Aotus vociferans and Nancy Ma's night monkey $A$. nancymaae, but we note that Brazilian traders we interviewed reported the capture of the black-headed night monkey $A$. nigriceps as well. Aotus vociferans is found in Colombia, east of the Cordillera Oriental and west of the Negro River, south to Brazil, north of the Amazon-Solimões River, to the Marañón River in Peru and into the Ecuadorian Amazon. A. nancymaae is found in Peru from the right bank of the Amazon River to the Marañón River, as well as in the enclave between the Tigre and Pastaza Rivers, and south of the Solimões River in Brazil. A. nigriceps occurs in Brazil south of the Amazon, west of the Tapajos-Juruena Rivers and into Peru (Aquino \& Encarnacion 1994, Groves 2005). A. nancymaae and $A$. nigriceps have been recorded in Brazil and Peru but only $A$. vociferans has been recorded in Colombia. However, although no official records exist, in the early 1980s J. Hernandez-Camacho and P. Hershkovitz observed both $A$. nancymaae and $A$. nigriceps - reportedly from Colombia - in the laboratories of the Fundacion Instituto de Inmunologia de Colombia in the early 1980s (Defler 2004).

All species of night monkeys are included in CITES Appendix II, which regulates all international and commercial trade. In the 3 countries discussed in this study, national legislation regarding the commercial exploitation of wildlife listed in the CITES Appendices is explicit. For instance in Colombia, Article IV (22 January 1981) of Law 17 states that commercial exploitation of wildlife listed in CITES Appendix II requires an export/import permit to be granted by the Environmental Ministry (www.siac.net.co/cites/ citesContenidoDetalle.jsp? codigo $=6 \&$, accessed on 28 April 2009). In the case of Brazil, Section II (21 September 2000) of Decree No. 3.607 declares that for the export/import of wildlife, it is necessary to obtain a license approved by the CITES Management Authority, Brazilian Institute of Environment and RenewableNatural Resources (IBAMA) (www.ibama.gov.br/faunasilvestre/areas-tematicas/exp-imp-cites/, accessed on 28 April 2009). Likewise in Peru, Law No. 27308 (16 July 2000) states that the National Institute for Natural Resources (INRENA) is the entity in charge of issuing permits for importing/exporting wildlife (INRENA 2003).

Aotus nancymaae, A. nigriceps and A. vociferans are listed by the International Union for Conservation of Nature (IUCN) as 'Least Concern', partially owing to their wide distribution (Cornejo \& Palacios 2008, 
Morales-Jiménez et al. 2008). While the IUCN listing suggests no major threats to these taxa, data to support this conjecture are meagre, since little fieldwork has been done in areas where human pressure is increasing, including the tri-border area. The IUCN has recently recommended the monitoring of the extraction, legal or otherwise, of $A$. vociferans and A. nancymaae in order to understand its effect on populations (Cornejo \& Palacios 2008).

\section{MATERIALS AND METHODS}

Reported levels of international trade. Data on international trade in night monkeys from Brazil, Colombia and Peru as reported by CITES Parties were retrieved from the World Conservation Monitoring Centre (WCMC) CITES database (www.unep-wcmc. org/citestrade, accessed 31 January 2009). We were interested in the trade in wild-caught individuals; thus all individuals that were listed as captive-bred, ranched or farmed were excluded. Data were available for 1975 to 2006, with some information being available for 2007 (not all Parties had submitted their reports at the time of the analysis); data for 2008 and 2009 were not yet available.

Assessment of trade in the tri-border area. Through a combination of field work and interviews, we assessed the illegal trade in night monkeys in the area of the Brazil-Colombia-Peru border triangle, roughly located along the south and north banks of the Amazon River, from Gamboa, Peru (41․ $\left.12.54^{\prime} \mathrm{S}, 70^{\circ} 04.64^{\prime} \mathrm{W}\right)$ to San Juan de Atacuari, Colombia $\left(3^{\circ} 48.35^{\prime} \mathrm{S}\right.$, $\left.70^{\circ} 40.20^{\prime} \mathrm{W}\right)$. We established that the total number of communities collecting night monkeys for biomedical research in the Brazil-Colombia-Peru border triangle is 28 (8 in Brazil, 5 in Colombia and 15 in Peru), involving an estimated 185 active traders/collectors. Interviews were conducted with members of 11 of these communities (comprising Tikuna, Yagua and Cocama indigenous groups and a minority of 'caboclos' or mixedancestry communities). We focussed on communities that had been capturing night monkeys on a regular basis and which still have permanent teams for this activity, although they are not full-time hunters and receive additional income from fishing and cultivation. For Peru and Colombia, this included all communities with $>4$ collectors but because of strict regulations restricting contact with indigenous people in Brazil, only one 'caboclos' community was visited. The aim was to interview about a third of the collectors/traders in each of the 11 communities; in all, 43 of 139 traders/ collectors who were reportedly active were interviewed.

Interviews were recorded from 28 May to 10 July 2008. Our research team consisted of a wildlife vet- erinarian specialising in primates, a sociologist and a Tikuna indigenous researcher. Some visits were accompanied by a Brazilian ex-trader who was well known in the Peruvian communities and acted as the interpreter in interviews with the Brazilian informants. As our interest was only in trade in night monkeys, we specified this before starting the interviews.

When arriving at each community, the team visited the indigenous authority (the 'Curaca' in Colombia and the 'Intendente Municipal' in Peru), in order to obtain consent to contact the collectors/traders. Informants were asked to participate voluntarily and they could withdraw at any time, without giving any reason. We asked the informants for permission to video or voice record the interviews and/or to take photos.

Some of the communities were revisited in order to interview key informants who were away during the first visit. The interview questionnaire was designed to provide information on (1) the number of night monkeys collected during the previous year by each person, including a phenotypic description of the animals; (2) the price and date of the last sale; (3) the buyer and the nature of the economic transaction; (4) capture techniques and training for capturing primates; (5) collection sites; (6) the number of years the informant had been involved in capturing monkeys; (7) the level of satisfaction regarding capture effort; (8) the price per animal; and (9) interest in participating in a conservation project for night monkeys.

\section{RESULTS}

\section{Reported international trade}

International trade in wild-caught night monkeys from Brazil, Colombia and Peru is largely restricted to Aotus trivirgatus, A. nancymaae and A. vociferans (Table 1). The international trade in A. trivirgatus is recorded from the period 1981-1994 when only an average of 250 wild-caught individuals were exported per year. Here, it is important to note that before Hershkovitz's (1983) assessment of the Aotus genus, all the night monkey species were considered as A. trivirgatus. Therefore, it is likely that the figures presented in Table 1 for $A$. trivirgatus in Peru correspond to either A. nancymaae or A. nigriceps as A. trivirgatus does not occur in Peru. Similarly, figures for A. trivirgatus for Colombia could correspond to A. griseimembra or $A$. brumbacki (Green 1978).

In this study, we only report the international trade in Aotus nancymaae and A. vociferans from 1994 onwards, when respective averages of 75 and 25 ind. were exported per year. 
Table 1. Numbers of wild-caught night monkeys listed as exported or originating from Brazil, Colombia or Peru on the World Conservation Monitoring Centre (WCMC) Convention on International Trade in Endangered Species of Wild Fauna and Flora (CITES) trade database (www.unep-wcmc.org/citestrade, accessed on 31 January 2009); animals or specimens listed as captivebred, ranched or farmed (source codes C, R or F) are excluded

\begin{tabular}{|llcc|}
\hline $\begin{array}{l}\text { Country } \\
\text { (acceded to CITES) }\end{array}$ & Species & $\begin{array}{c}\text { Numbers } \\
\text { exported }\end{array}$ & Period \\
\hline Brazil (1975) & Aotus trivirgatus & 2 & $1981-1987$ \\
Colombia (1981) & $\begin{array}{l}\text { Aotus trivirgatus } \\
\text { Aotus lemurinus }\end{array}$ & 1446 & $1981-1989$ \\
Peru (1975) & $\begin{array}{l}\text { Aotus trivirgatus } \\
\text { Aotus nancymaae }\end{array}$ & 1843 & 1999 \\
& $\begin{array}{l}\text { Aotus vociferans } \\
\text { Aotus spp. }\end{array}$ & 265 & $1989-1994$ \\
& & 30 & $1994-2004$ \\
& & & $1981-1994$ \\
\hline
\end{tabular}

captured, which agreed with descriptions published by Aquino \& Encarnacion (1988, 1994) and Ford (1994). All communities reported trade in A. nancymaae, the Colombian and Brazilian communities mentioned that they captured small numbers of $A$. vociferans, and descriptions from Brazilian and Peruvian traders suggest the possibility that $A$. nigriceps is traded as well. Local people from each country of the tri-border region of the Amazonia did not have different names for each species of the genus Aotus; night monkeys are called 'buri-buri' in Colombia, 'musmuqui' in Peru and 'macaco da noite' in Brazil.

\section{Trade in the Brazil-Colombia-Peru tri-border area}

The 11 communities reported an extensive trade in night monkeys, with between 144 and 700 ind. reportedly being captured annually per community, giving a total of $\sim 4000$ ind. per year (Table 2). On average, each community had been catching night monkeys for a period of 12 yr, with 5 communities active in 2008. Regarding species composition, informants described marked phenotypic differences between Aotus nancymaae and $A$. vociferans, but it was more difficult to confirm differences between $A$. nancymaae and $A$. nigriceps. The Brazilian collectors gave detailed descriptions of 2 different monkey species based on fur colouration and sleeping sites where the animals were
The traders and collectors who were interviewed understood that cross-border trade was illegal without a permit. Their justification for these illegal practices is their lack of access to cash needed for commodities such as petrol and school uniforms. While the interviewees were from a wide range of communities from 3 different countries, all agreed that the end-buyer of the night monkeys they captured was a local laboratory in the Amazonas Department in Colombia, close to the tri-border area. Interviewees in Peruvian communities indicated that personnel from this laboratory visited them regularly to order night monkeys, allegedly for use in the laboratory. The laboratory had a permit granted by the regional environmental authority (Corpoamazonia 2006) to acquire 1600 Aotus

Table 2. Overview of trade in night monkeys Aotus spp. in the Brazil-Colombia-Peru tri-border area for the period 2007-2008

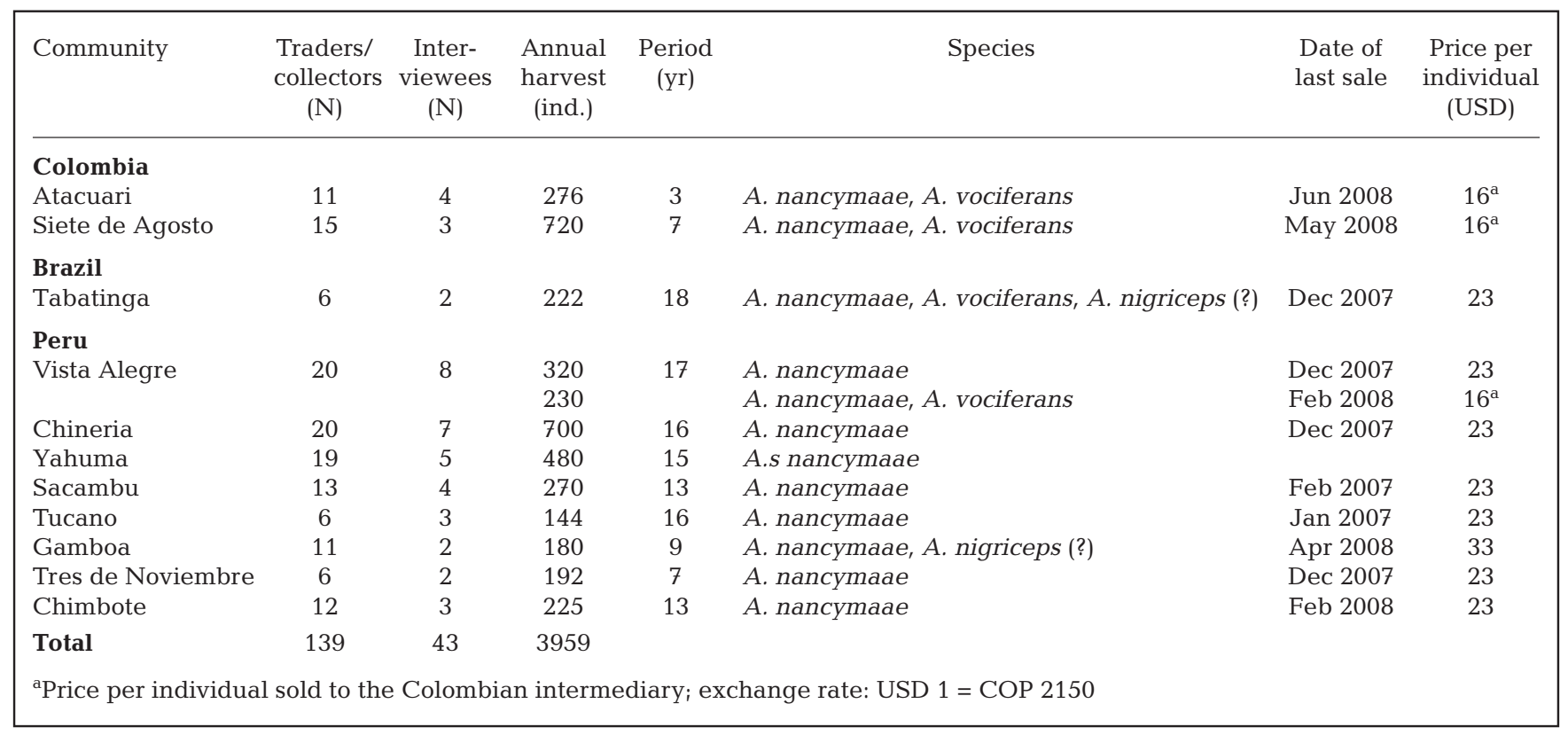


vociferans over a 2 yr period (2006-2008) in Colombia (Resolution 00066, 13 September 2006). Prices paid by Colombian intermediaries in all 3 countries were in Colombian pesos (COP), and ranged between USD 23 per individual in 2007 to USD 33 per individual in 2008.

A Brazilian trader who had collected and sold 2000 night monkeys over an $18 \mathrm{yr}$ period, stated that after being captured twice by the Colombian police in 2007 , he decided to stop collecting monkeys. This incident alerted the Peruvian traders who then began to use other methods to continue the trade in monkeys. Collectors from Vista Alegre in Peru subsequently started selling night monkeys to a Colombian intermediary located in Siete de Agosto (Colombia), who had a legal permit to provide monkeys to the laboratory, provided that the trader originated from Colombia. This intermediary paid only half (USD 16) of the price paid by the laboratory, but the Peruvian collectors maintained that this way was safer, as they were not exposed to capture by the Colombian police. Other Peruvian collectors stated that they continued to sell night monkeys directly to the laboratory using Colombian identity cards belonging to relatives or friends, thus concealing their nationality. Trapping night monkeys is a family activity where usually at least 3 members of the team of $\sim 5$ are relatives. The interviewees were described as the leaders of the capture teams and were usually the people in charge of making the economic transaction and paying the rest of the team.

\section{Monetary value}

Data for annual harvest were calculated from the approximate number of monkeys captured by the informant's team during the previous year. These figures were multiplied by the total number of teams in each community. Informants from different communities agreed that a team captured from 8 to 15 monkeys per month, depending on the demand. These figures indicate that the annual harvest of night monkeys in the area is $\sim 4000$ animals. At an average price of USD 23-33 per individual, this suggests a total annual monetary value of USD 90000 for the collectors (averaging USD 625 per collector) plus USD 20000 for the Colombian intermediaries.

\section{DISCUSSION}

The results of the interviews suggest that there is an extensive and continuing trade in night monkeys in the tri-border area of Brazil, Colombia and Peru. This represents trade within Colombia, between Peru and Colombia and between Brazil and Colombia. While the estimated domestic trade in Colombia is in the order of 1000 ind. per year, the estimated international trade is $3 \times$ this number. No import of night monkeys from Peru or Brazil is reported by Colombia, nor does Peru or Brazil report the export of night monkeys to Colombia. The assertion by those involved in the trade in all 3 countries that prices were paid in Colombian currency supports the suggestion that trade is primarily for the Colombian market. If correct, and with all 3 countries being Party to CITES, this highlights violation of CITES regulations. All people involved in the trade in night monkeys in the tri-border area that we contacted indicated that the monkeys were sold to a single laboratory in the Amazonas Department of Colombia.

Our understanding, supported by government documentation, is that this laboratory was allowed to legally acquire up to 1600 Aotus vociferans within Colombia over a 24 mo period. The interview data suggest not only that a much larger number of individuals was acquired, but also that these represented different species (primarily A. nancymaae), and included a substantial number of individuals from outside Colombia. Publications resulting from research conducted at the facility in the Amazonas Department indicate that indeed both $A$. nancymaae and A. nigriceps are used (e.g. Cardenas et al. 2005, Spirig et al. 2005, Baquero et al. 2006, Patarroyo et al. 2006, Suarez et al. 2006, Daubenberger et al. 2007).

Long-term studies suggest that even common species such as rhesus macaques can become severely threatened if harvested unsustainably (Southwick \& Siddiqi 2001). In the case of Aotus spp. in the tri-border area, interviewees confirmed that it now takes considerably more time to trap the same number of night monkeys, with many hunting trips proving unsuccessful as animals are becoming difficult to find. The ecological effects of the continuous extraction of Aotus spp. since 1984 in the Brazil-Colombia-Peru border are unknown. As all night monkeys are listed in Appendix II of CITES, Parties are obliged to report international trade in these species. In recent years (2003 onwards), only Peru has reported international trade in night monkeys, both captive-bred and wild-caught, with all specimens going to the USA. The reported high levels of trade among the 3 countries in the triborder area are in stark contrast with what has been reported as international export, suggesting a lack of enforcement of international trade regulations.

\section{RECOMMENDATIONS}

The significant levels of harvest of night monkeys in the Brazil-Colombia-Peru tri-border area appear to be in violation of both national and international laws 
and regulations. For instance under Colombian legislation, Article 85 (22 December 1993) of Law 99 clearly states fines and sanctions that should be applied in cases of illegal import of wildlife, with fines and sanctions varying depending on the gravity of the infraction (www.siac.net.co/cites/citesContenidoDetalle.jsp? codigo=11, acccessed on 28 April 2009).

We strongly recommend that environmental and conservation authorities in Colombia, Peru and Brazil try to resolve this through cooperative action. The international nature of the trade, which violates CITES regulations, makes the CITES Management Authorities in each of the 3 countries the best bodies to take the lead in this process.

We furthermore urge the Colombian Ministry of the Environment to investigate the species composition, origin and volumes of night monkeys used in the biomedical laboratory in the Amazonas Department as data from collectors and traders suggest that these numbers are not in correspondence with national permits. If animals are to be acquired from Brazilian or Peruvian sources in the future, this has to be with official permits from the respective national authorities.

Our research also indicated the presence of 3 species of night monkeys, viz. Aotus vociferans, A. nancymaae and $A$. nigriceps, in areas where they have not been reported before. We urge field workers to investigate this further to establish the species' precise geographic distribution and whether or not they show allopatric or sympatric distribution. Data on their abundance may also provide an incentive to further protect these species if numbers are proven to be low.

Acknowledgements. We thank the research team and members of 2 local nongovernment organizations who prefer to remain anonymous, for their valuable support during field work; anonymous collaborators from the environmental police in Leticia; staff from the Procuraduria Ambiental (Bogota, Colombia) for providing hard copies of legal documents; the Amacayacu National Park for providing logistical support; and B. Ortiz, T. R. Defler, B. Milton and S. Racca for providing valuable suggestions for the improvement of this paper. We also thank C. R. Shepherd and 2 anonymous reviewers for their helpful comments on this manuscript. The research was funded by Animal Defenders International (UK), and forms part of the PhD programme of A.M.M. funded by a Russell E. Train fellowship (WWF-US) and the Overseas Research Students Award Scheme, UK. The views presented do not necessarily reflect the views or policies of the funding agencies, and the funders had no role in study design, data collection and analysis, decision to publish, or preparation of the manuscript.

\section{LITERATURE CITED}

Aquino R, Encarnacion F (1988) Population densities and geographic distribution of night monkeys (Aotus nancymai and Aotus vociferans) (Cebidae: Primates) in northeastern Peru. Am J Primatol 14:375-381
Aquino R, Encarnacion F (1994) Owl monkey populations in Latin America: field work and conservation. In: Baer JF, Weller RE, Kakoma I (eds) Aotus: the owl monkey. Academic Press, San Diego, CA, p 59-95

Bailey RC, Backer RS, Brown DS, Von Hildebrant P, Mittermeier RA, Sponsel LE, Wolf KE (1974) Progress of a breeding project for non-human primates in Colombia. Nature 248:453-455

Baquero JE, Miranda S, Murillo O, Mateus $\mathrm{H}$ and others (2006) Reference strand conformational analysis (RSCA) is a valuable tool in identifying MHC-DRB sequences in three species of Aotus monkeys. Immunogenetics 58: 590-597

> Cardenas PP, Suarez CF, Martinez P, Patarroyo ME, Patarroyo MA (2005) MHC class I genes in the owl monkey: mosaic organisation, convergence and loci diversity. Immunogenetics 56:818-832

Castro N (1978) Diagnostico de la situación actual de los primates no humanos en el Peru y un plan nacional para su utilización racional. Ministerio de Agricultura y Alimentación, Dirección General Forestal y de Fauna, Dirección de Conservación, Lima

Cornejo F, Palacios E (2008) Aotus nigriceps. IUCN Red List of Threatened Species. www.iucnredlist.org, accessed 27 Dec 2008

Corpoamazonia (2006) Resolucion No. 00066. A través de la cual se otorga a la Fundación Instituto de Inmunología de Colombia (FIDIC) un permiso de investigación denominada 'Captura y estudio de investigación científica en diversidad biológica de primates en la cuenca del Río Amazonas en el trapecio amazónico colombiano'. Corpoamazonia, Leticia, p 17

Daubenberger CA, Spirig R, Patarroyo ME, Pluschke G (2007) Flow cytometric analysis on cross-reactivity of humanspecific CD monoclonal antibodies with splenocytes of Aotus nancymaae, a non-human primate model for biomedical research. Vet Immunol Immunopathol 119: $14-20$

Defler TR (2004) Primates of Colombia. Conservation International, Bogota, DC, p 550

Defler TR, Bueno ML (2007) Aotus diversity and the species problem. Primate Conserv 22:55-70

Defler TR, Bueno ML, Hernandez-Camacho J (2001) Taxonomic status of Aotus hershkovitzi: its relationship to Aotus lemurinus lemurinus. Neotrop Primates 9:37-52

Ford SM (1994) Taxonomy and distribution of the owl monkey. In: Baer JF, Weller RE, Kakoma I (eds) Aotus: the owl monkey. Academic Press, San Diego, CA, p 1-57

Freese C (1975) A census of non-human primates in Peru. In: PAHO (ed) Primate censusing studies in Peru and Colombia. Pan American Health Organization, Washington, DC, p $17-42$

Green KM (1978) Primate censusing in northern Colombia: a comparison of two techniques. Primates 19:537-550

Groves CT (2005) The primates. In: Wilson DE, Reeder DAM (eds) Mammal species of the world: a taxonomic and geographic reference, 3rd edn. Johns Hopkins University Press, Baltimore, MD

> Held JR, Wofle TL (1994) Imports: current trends and usage. Am J Primatol 34:85-96

Heltne PG, Freese C, Whitesides AG (1975) Field survey of non-human primate populations in Bolivia. Pan American Health Organization, Washington, DC

Hernandez-Camacho J, Cooper WR (1976) The non-human primates of Colombia. In: Thornigton WR, Heltne PG (eds) Neotropical primates: field studies and conservation. National Academy of Sciences, Washington, DC, p 35-69 
Hernandez-Camacho J, Defler TR (1989) Algunos aspectos de la conservación de primates no-humanos en Colombia. In: Saavedra CJ, Mittermeier RA, Bastos Santos I (eds) La primatologia en Latinoamérica. WWF-US, Washington, DC, p 67-100

Hershkovitz P (1983) Two new species of night monkeys, genus Aotus (Cebidae, Platyrrhini): a preliminary report on Aotus taxonomy. Am J Primatol 4:209-243

INRENA (2003) Ley forestal y de fauna Silvestre. Ley No. 27308. Reglamento de la Ley Forestal y de Fauna Silvestre y de sus modificaciones. D.S. N 0142001-AG. Instituto Nacional de Recursos Naturales, Lima, p 112

Mittermeier RA (1991) Hunting and its effect on wild primate populations in Surinam. In: Robinson JG, Redford $\mathrm{KH}$ (eds) Neotropical wildlife use and conservation. The University of Chicago Press, Chicago, IL p 93-107

Mittermeier RA, Konstant WR, Mast RB (1994) Use of Neotropical and Malagasy primate species in biomedical research. Am J Primatol 34:73-80

Morales-Jiménez AL, Link A, Cornejo F, Stevenson PR (2008) Aotus vociferans. IUCN Red List of Threatened Species. www.iucnredlist.org, accessed 27 Dec 2008

Muckenhirn NB, Mortensen K, Vessey S, Fraser CEO, Singh B (1975) Report on a primate survey in Guyana. Pan American Health Organization, Washington, DC

Neville MK (1975) Census of primates in Peru. Pan American Health Organisation Sci Publ 317:19-29

Neville M K (1977) Censo de primates en el Perú. Primera Conferencia Internacional Sobre la Conservación y Utilización de Primates Americanos No-Humanos en las

Editorial responsibility: Mike Bruford,

Cardiff, UK
Investigaciones Biomédicas. Organización Panamericana de Salud Publicaciones Científicas, Lima, p 20-31

Patarroyo ME, Cifuentes G, Baquero J (2006) Comparative molecular and 3-dimensional analysis of the peptideMHC II binding region in both human and Aotus MHCDRB molecules confirms their usefulness in antimalarial vaccine development. Immunogenetics 58: 598-606

Ruiz-Herrera A, Garcia F, Aguilera M, Garcia M, Ponsa Fontanals M (2005) Comparative chromosome painting in Aotus reveals a highly derived evolution. Am J Primatol 65:73-85

Smith NJ (1977) Influências ecológicas e culturais na produtividade agrícola ao longo da Transamazônica. Acta Amazonica $7(1): 23-38$

Smith NJ (1978) Human exploitation of terra firme fauna in Amazonia. Cienc Cult 30:17-23

Southwick CH, Siddiqi MF (2001) Status conservation and management of primates in India. In: Gupta AK (ed) Non-human primates of india. ENVIS bulletin: wildlife and protected areas. Wildlife Institute of India, Dehradun p 81-91

Spirig R, Peduzzi E, Patarroyo ME, Pluschke G, Daubenberger CA (2005) Structural and functional characterisation of the Toll like receptor 9 of Aotus nancymaae, a nonhuman primate model for malaria vaccine development. Immunogenetics 57:283-288

Suarez CF, Patarroyo ME, Trujillo E, Estupinan M, Baquero JE, Parra C, Rodriguez R (2006) Owl monkey MHC-DRB exon 2 reveals high similarity with several HLA-DRB lineages. Immunogenetics 58:542-558

Submitted: February 9, 2009; Accepted: May 21, 2009 Proofs received from author(s): August 18, 2009 